PATIK : Jurnal Hukum

https://ejournal.uhn.ac.id/index.php/patik

Volume 10 Nomor 01 April 2021 Page : 15 - 24

p-issn : $2086-4434$

\title{
PERTANGGUNGJAWABAN PIDANA TERHADAP PELAKU YANG MENAWARKAN PEKERJAAN PROSTITUSI ONLINE (STUDI PUTUSAN NO: 70/Pid.Sus/2019/PN BJN)
}

\author{
Andreas Bilian Simanjuntak, July Esther, Herlina Manullang \\ Fakultas Hukum, Universitas HKBP Nommensen \\ julyesther@uhn.ac.id
}

\begin{abstract}
Abstrak
Prostitusi di Indonesia dianggap sebagai kesusilaan atau melawan hukum dan menjadi masalah yang rumit oleh karena itu masalah ini sangat butuh perhatian khusus dari masyarakat. Bagaimana Pertanggungjawaban Pidana Pelaku Yang Menawarkan Pekerjaan Prostitusi Online (Studi Kasus Putusan No 70/Pid.Sus/2019/PN Bjn). Adapun penelitian ini metode analisis yang dilakukan untuk mengumpulkan data dengan cara studi kepustakaan. Dalam perkara putusan Nomor 70/Pid.Sus/2019/Pn Bjn, Jaksa mendakwa terdakwa dengan dakwaan kesatu yakni Pasal 27 Ayat (1) jo Pasal 45 Ayat (1) UU RI No 19 tahun 2016 tentang perubahan atas UU No 11 tahun 2008 tentang ITE dan unsur-unsur dalam pasal tersebut telah terpebuhi dan dakwaan kedua Pasal 296 KUHP dan unsur-unsur dalam dakwaan tersebut telah terpenuhi. Maka Jaksa hanya menuntut terdakwa dengan dakwaan kedua yaitu selama 1 (satu) tahun. Majelis Hakim tidak menemukan hal-hal yang dapat menghapuskan pertanggungjawaban pidana sebagai alasan pembenar dan alasan pemaaf, maka terdakwa harus mempertanggungjawabkan perbuatan dan karena terdakwa mampu bertanggungjawab maka harus dinyatakan bersalah dan dijatuhi pidana penjara selama satu 1 (satu) tahun 2 (dua) bulan. Perlu penindakan secara tegas terhadap pelaku prustitusi online, maka diharapkan kepada Aparat Penegak Hukum terutama Hakim memberikan sanksi yang berat agar pelaku tindak pidana prostitusi online mendapatkan efek jera.
\end{abstract}

\section{Kata kunci : Dakwaan, Prostitusi online, Tindak Pidana, Pertanggungjawaban}

Prostitution in Indonesia is considered decency or against the law and is a complicated problem, therefore this problem really needs special attention from the public. What is the Criminal Accountability of Perpetrators Who Offer Online Prostitution Jobs (Case Study of Decision No. 70 / Pid.Sus / 2019 / PN Bjn). As for this research, the method of analysis is carried out to collect data by means of literature study. In the case of decision Number 70 / Pid.Sus / 2019 / Pn Bjn, the prosecutor charged the defendant with the first indictment, namely Article 27 Paragraph (1) in conjunction with Article 45 Paragraph (1) of the Republic of Indonesia Law No. 19 of 2016 concerning amendments to Law No.11 of 2008 concerning ITE and the elements in the article have been fulfilled and the second indictment of Article 296 of the Criminal Code and the elements in the indictment have been fulfilled. The Panel of Judges did not find anything that could abolish criminal responsibility as a justification and excuse, so the defendant had to be accountable for the act and because the defendant was able to be responsible he had to be found guilty and sentenced to imprisonment for one 1 (one) year 2 (two) months. It is necessary to take firm action against perpetrators of online prostitution, it is hoped that Law Enforcement Officials, especially Judges, will provide severe sanctions so that online prostitution offenders will have a deterrent effect.

Keywords: Indictment, online prostitution, Crime, Accountability 


\section{Pendahuluan}

Teknologi merupakan salah satu unsur dalam kehidupan yang megalami perkembangan dari waktu ke waktu. teknologi informasi memegang peran penting, baik di masa kini maupun di masa mendatang. Kemajuan teknologi di era globalisasi membuat informasi begitu cepat beredar luas. Hanya dalam hitungan detik, suatu peristiwa sudah bisa langsung tersebar dan diakses oleh pengguna internet melalui media sosial. Seiring dengan perkembangan, teknologi informasi dengan sendirinya juga merubah perilaku masyarakat. Perkembangan teknologi informasi telah menyebabkan dunia menjadi tanpa batas dan menyebabkan perubahan sosial yang sangat cepat. Sehingga dapat dikatakan teknologi informasi saat ini menjadi pedang bermata dua, karena selain memberikan kontribusi bagi peningkatan kesejahteraan, kemajuan, dan peradaban manusia, sekaligus menjadi sarana efektif perbuatan melawan hukum.

Perkembangan teknologi terebut memberikan pengaruh positif bagi masyarakat diantaranya mempermudah melakukan pekerjaan dalam mendapatan informasi, namun selain itu terdapat juga dampak negatif terhadap perkembangan teknologi, salah satunya ialah kegiatan prostitusi yang dilakukan melalui media elektronik (internet) atau yang dikenal dengan prostitusi online. Pengertian prostitusi online adalah gabungan dua kata yaitu prostitusi dan online, pengertian prostitusi menurut Kamus Besar Bahasa Indonesia adalah pertukaran hubungan seksual dengan uang atau hadiah-hadiah sebagai sesuatu transaksi perdagangan, prostitusi diartikan juga sebagai pelacuran orang yang melakukan perbuatan prostitusi disebut pelacur yang dikenal juga dengan WTS atau Wanita Tuna Susila. Pengertian kata Online berasal dari bahasa inggris yang diartikan terhubung. Sehingga apabila digabungkan dua kata tersebut akan mengandung pegertian sebagai praktek prostitusi atau pelacuran atau pengertian lain mengenai prostitusi dengan cara menggunakan media internet atau online sebagai sarana transaksi bagi para pekerja seks komersial dan yang ingin menggunakan jasanya Prostitusi merupakan peristiwa penjualan diri dengan memperjual belikan badan, kehormatan dan kepribadian kepada banyak orang untuk memuaskan nafsu-nafsu seks dengan suatu imbalan pembayaran.

Prostitusi di Indonesia dianggap sebagai kesusilaan atau melawan hukum dan menjadi masalah yang rumit oleh karena itu masalah ini sangat butuh perhatian khusus dari masyarakat. Prostitusi sebuah bisnis yang indentik dengan dunia hitam ini merupakan salah satu bisnis yang mendatangkan uang dengan cepat tidak memerlukan modal banyak, hanya berdampak pada mereka yang melakukannya yaitu para pelaku dan pemakai jasanya, melainkan juga berdampak pada masyarakat luas, prostitusi online bahkan membahayakan bagi kehidupan rumah tangga yang terjalin sampai bisa menimbulkan tindak pidana kejahatan dan lain sebagainya ${ }^{1}$. Dalam Kriminalistik selaku ilmu penyelidikan kejahatan dapat membuktikan bahwa pelacuran adalah suatu perbuatan yang bertentangan dengan norma agama, kesusilaan, dan norma kesopanan tetapi ternyata sampai saat ini tidak ada seorang pelacur dihukum karena melacurkan dirinya dimana hukuman atau pemidanaan terhadap pelacur tersebut (wanita tuna susila) didasarkan pada KUHP Inkasu Buku II Bab XIV tentang kejahatan terhadap kesusilaan. Berdasakan uraian diatas, maka yang menjadi permasalahnnya sebagai berikut: Bagaimana Pertanggungjawaban Pidana Pelaku Yang Menawarkan Pekerjaan Prostitusi Online (Studi Kasus Putusan No 70/Pid.Sus/2019/PN Bjn)

\footnotetext{
${ }^{1}$ Kartini Kartono, Patologi Sosial, Jakarta: Raja Grafindo Persada, 2015
} 


\section{Tinjauan Pustaka}

Konsep liability atau "pertanggungjawaban" dalam hukum pidana merupakan konsep sentral yang dikenal dengan ajaran kesalahan. Dalam bahasa latin ajaran kesalahan dikenal dengan sebutan mens rea. Doktrin mens rea ini dilandaskan pada konsepsi bahwa suatu perbuatan tidak mengakibatkan seseorang bersalah kecuali jika pemikiran orang itu jahat. Didalam doktrin itu, terdapat dua syarat yang harus dipenuhi untuk dapat memidana seseorang, yaitu ada perbuatan lahirlah yang terlarang/tindak pidana (actus reus) da nada sikap batin jahat/tersela (mens rea) ${ }^{2}$

Pertanggungjawaban pidana di artikan sebagai terusan celaan yang objektif yang ada pada perbuatan pidana dansecara subjektif yang ada memenuhi syarat untuk dapat dipidana karena perbuatannya itu. Dasar adanya perbuatan pidana adalah asas legalitas, sedangkan dasar dapat dipidana pembuat adalah asas kesalahan. Ini berarti bahwa pembuat perbuatan pidana hanya akan dipidana jika ia mempunyai kesalahan dan melakukan perbuatan pidana tersebut. Pertanggungjawaban pidana pada hakikatnya merupakan mekanisme yang dibangun oleh hukum pidana untuk beraksi terhadap pelanggaranatas "kesepakatan menolak" suatu perbuatan tertentu. ${ }^{3}$

Beberapa pengertian pertanggungjawaban pidana yang dikemukakan oleh beberapa sarjana antara lain. Menurut Sudarto pertanggungjawaban pidana adalah dipidananya seseorang tidaklah cukup apabila orang itu telah melakukan perbuatan yang bertentangan dengan hukum atau bersifat melawan hukum. Jadi, meskipun perbuatan tersebut memenuhi rumusan delik dalam undang-undang dan tidak dibenarkan, namun hal tersebut belum memenuhi syarat penjatuhan pidana, yaitu orang yang melakukan perbuatan itu mempunyai kesalahn atau bersalah. Orang tersebut harus dipertanggungjawabkan atas perbuatannya atau jika dilihat dari sudut perbuatannya, perbuatannya baru dapat dipertanggungjawabkan kepada orang tersebut. ${ }^{4}$ Menurut Moeljatno Pertanggungjawaban adalah orang tidak mungkin dipertanggungjawabkan (dijatuhi pidana) kalau dia tidak melakukan perbuatan pidana. $^{5}$ Konsep pertanggungjawaban pidana sesungguhnya tidak hanya mengangkat soal hukum semata melainkan juga menyangkut soal nilai-nilai moral atau kesusilaan umum yang dianut oleh masyarakat. Seseorang yang mendapat putusan pengadilan yang sudah mempunyai kekuatan hukum yang tetap (artinya tidak melakukan upaya hukum lagi) harus menjalankannya. ${ }^{6}$ Sehingga untuk memidanakan pelaku yang melakukan yang perbuatan tindak pidana, selain telah terbukti melakukan tindak pidana maka harus mengenai unsur kesalahan yang disengaja atau pun kealpaan. ${ }^{7}$

Pertanggungjawaban pidana pada hakikatnya merupakan suatu mekanisme yang dibangun oleh hukum pidana untuk bereaksi terhadap pelanggaran atas 'kesepakatan menolak' suatu perbuatan tertentu. ${ }^{8}$ Perbuatan pidana hanya menunjuk kepada dilarangnya perbuatan. Apakah orang yang telah melakukan perbuatan itu kemudian juga dipidana, tergantung pada soal, apakah dia dalam melakukan perbuatan itu mempunyai kesalahan atau tidak. Apabila orang yang melakukan perbuatan pidana itu memang mempunyai kesalahan, maka tentu dia akan dipidana. Asas yang tidak tertulis: "tidak dipidana jika tidak ada kesalahan", merupakan dasar dari pada dipidananya sipembuat. ${ }^{9}$

\footnotetext{
${ }^{2}$ Mahrus Ali, Asas-Asas Hukum Pidana Korporasi, Raja Grafindo Persada, 2015, Hal.93.

${ }^{3}$ Mahrus Ali, Dasar-Dasar Hukum Pidana, Sinar Grafika, Jakarta, 2015, Hal.156.

${ }^{4}$ Mahrus Ali, Op.cit, Hal 95.

${ }^{5}$ Kasman Siburian, Hukum Administrasi Negara, Capiah, Yogyakarta, 2017, Hal202.

${ }^{6}$ Herlina Manullang, Pengantar Ilmu Hukum Indonesia, UHN Pres, Medan, 2010, Hal 89.

${ }^{7}$ Hanafi Amrani, Sistem Pertanggungjawaban Pidana, Rajawali Pres, Jakarta, 2015, Hal 52.

${ }^{8}$ Mahrus Ali, Op.cit, Hal.94.

${ }^{9}$ Roeslan Saleh, Perbuatan Pidana Dan Pertanggungjawaban Pidana, Jakarta, Aksara Baru, Hal.75.
} 


\section{PATIK : JURNAL HUKUM Vol : 10 No. 1 April 2021, Hal 15 - 24}

Menurut Roeslan Saleh tidaklah ada gunanya untuk mempertanggungjawabkan terdakwa atas perbuatannya apabila perbuatannya itu sendiri tidak bersifat melawan hukum, maka lebih lanjut dapat pula dikatakan bahwa terlebih dahulu harus ada kepastian tentang adanya perbuatan pidana, dan kemudian semua unsur-unsur kesalahan harus dihubungkan pula dengan perbuatan pidana yang dilakukan, sehingga untuk adanya pertanggungjawaban pidana yang mengakibatkan dipidanannya terdakwa maka terdakwa haruslah ada unsur-unsur pertanggungjawaban pidana sebagai berikut $:^{10}$

a) Melakukan perbuatan pidana;

Unsur perbuatan merupakan salah satu unsur yang pokok pertanggungjawaban pidana, karena seseornag tidak dapat dipidana apabila tidak melakukan suatu perbuatan dimana perbuatan yang dilakukan merupan perbuatan yang dilarang oleh undang-undang hal itu sesuai dengan asas legalitas yang kita anut. Asas legalitas nullum delictum nulla poena sine praevia lege poenali artinya tidak dipidana suatu perbuatan apabila tidak ada Undnag-Undang atau aturan yang mengatur mengenai larangan perbuatan tersebut.

b) Mampu bertanggung jawab;

Mampu bertanggungjawab. Dalam hal ini pelaku menyadari perbuatannya tersebut dapat merugikan orang lain adanya perbuatan yang dilakukan pelaku dengan adanya niat yang bersifat tujuan sehingga perbuatannya tersebut dapat dipertanggungjawaban.

c) Dengan kesengajaan atau kealpaan;

Agar terpenuhinya suatu perbuatan sebagai suatu tindak pidana harus memenuhi unsur sifat melawan hukum dan kesalahan. Kesalahan dalam arti luas, meliputi sengaja. Kelalaian (Culpa) dan Dapat Dipertanggungjawabkan. Memang tidak mudah untuk membedakan antara kesengajaan dengan sadar kepastian dan kesengajaan dalam sadarkemungkinan, karena diduanya didalam batin manusia.

d) Tidak adanya alasan pemaaf;

Hal ini merupakan suatu pertimbangan hukum dalam menjatuhkan hukuman bagi pelaku dengan berdasarkan perbuatan pelaku tidak adanya alasan pemaaf sehingga perbuatan pelaku dapat dihukum sesuai dengan ketentuan undang-undang yang berlaku.

Pengertian kesalahan tidak dapat dijumpai dalam undang-undang hukum pidana (KUHP) maupun undang-undang khusus yang mengatur tentang hukum pidana. Tidak adanya pengertian kesalahan dalam undang-undang ini menimbulkan banyaknya pengertian tentang kesalahan dalam doktrin-doktrin di lapangan ilmu hukum pidana yang dikembangkan oleh para ahli hukum pidana. Pengertian kesalah yang bermacam-macam yang disampingkan oleh para ahli hukum pidana ini melahirkan beberapa teori tetang kesalahan. ${ }^{11}$

Dikatakan bahwa "kesalahan" dalam hukum pidana terdiri atas kesengajaan dan atau kealpaan. Dan biasanya dipandang sebagai "kesengajaan" adalah melakukan sesuatu, "dengan menghendaki dan menghantui". Lebih jauh dikenal bentuk-bentuk kesengajaan

\footnotetext{
${ }^{10}$ Roeslan Saleh, Pikiran-pikiran Tentang Pertanggungjawaban Pidana, Ghalia Indonesia, Jakarta, 1982, Hal.10

${ }^{11}$ Agus Rusianto, Tindak Pidana Dan Pertanggungjawaban Pidana, Jakarta, Prenadamedia Grup, 2018, Hal.37.
} 
sebagai maksud, kesengajaan sebagai keharusan, dan kesengajaan yang biasanya diajarkan oleh buku-buku pelajaran hukum pidana. ${ }^{12}$

Pompe berpendapat bahwa pengertian kesalahan mempunyai tanda sebagai hal yangs tercela (verwijtbaarheid) yang padahakikatnya tidak mencegah (vermijdbaarheid) kelakukan yang bersifat melawan hukum (der wederrechtelijke gedraging). Kemudian dijelaskan pula tentang hakikat tidak mencegah kelakukan yang bersifat melawan hukum (verwijtbaarheid der wederrechtelijke gedraging) di dalam perumusan hukum positif, disitu berarti mempunyai kesengajaan dan kealpaan (opzet en onachzaamheid) yang mengarah kepada sifat melawan hukum (wederrechtelijkheid) dan kemampuan bertanggungjawab (toerekenbaarheid). ${ }^{13}$

Kantorowicz bahwa kesalahan terdiri atas tiga unsur yaitu : Zurechnugnsfahigkeit (kemampuan bertanggungjawab), Zurechbarkeit (ada kesengajaan atau kealpaan) dan Zumutbarkeit (dapat diharapkan), maka mengenai yang pertama disetujui penuh, bahwa itu berhubungan dengan sifat-sifat pribadi dader sendiri, karena yang diseliki ialah, apakah jiwanya normal atau tidak. Sebaliknya Zumutbarkeit, yaitu bahwa terdakwa dapat diharapkan berbuat lain daripada perbuatan yang telah dilakukan, itu pandangan mengenai strafbaarheid feit. ${ }^{14}$

Dahulu terdapat anggapan kesalahan dalam hukum pidana itu identic dengan kesengajaan atau kealpaan. Akan tetapi lambat laun tumbuh pendapat bahwa kesalahan itu bukannya hanya terdiri atas kesengajaan atau kealpaan saja, melainkan masih ada unsur batin lainnya berupa kemampuan bertanggung jawab dan unsur tidak adanya alasan pemaaf. $^{15}$ Jadi untuk adanya kesalahan, hubungan antara keadaan batin dengan perbuatannya (atau dengan suatu keadaan yang menyertai perbuatannya) yang menimbulkan celaan tadi harus berubah kengajaan atau kealpaan.

Dikatakan bahwa kesengajaan (dolus) dan kealpaan (culpa) adalah bentuk-bentuk kesalahan (schuldvormen). ${ }^{16}$ Kedua hal tersebut dibedakan, "kesengajaan" adalah dikehendaki, sedang "kealpaan" adalah tidak dikehendaki. Umumnya para pakar sependapat bahwa "kealpaan" adalah bentuk kesalahan yang lebih ringan dari "kesengajaan". Itulah sebabnya, saksi atau ancaman hukuman terhadap pelanggaran norma pidana yang dilakukan dengan "kealpaan", lebih ringan. ${ }^{17}$

D.Simons menerangkan "kealpaan" tersebut sebagai berikut. Umumnya kealpaan itu terdiri atas dua bagian, yaitu tidak berhati-hati melakukan suatu perbuatan, disamping dapat menduga akibat perbuatan itu. Namun, meskipun suatu perbuatan dilakukan dengan hati-hati, masih mungkin juga terjadi kealpaan jika yang berbuat itu telah mengetahui bahwa dari perbuatan itu mungkin akan timbul suatu akibat yang dilarang undangundang. ${ }^{18}$ Menurut teori in kauf nehmen untuk adanya kesengajaan diperlukan dua syarat:

a. Terdakwa mengetahui kemungkina adanya akibat keadaan yang merupakan delik.

b. Sikap terhadap kemungkinan itu andaikata sungguh timbul, ialah apa boleh, dapat disetujui dan berani pikul resikonya. ${ }^{19}$

\footnotetext{
${ }^{12}$ Roeslan Salah, Perbuatan Dan Kesalahan Dalam Hukum Pidana, Jakarta, Aksara Baru, 1985 , Hal.49

${ }^{13}$ Bambang Poernomo, Asas-Asas Hukum Pidana, Jakarta, Ghalia Indonesia, 2018, Hal.135.

${ }^{14}$ Moeljatno, Perbuatan Pidana dan Pertanggungjawaban dalam Hukum Pidana, Jakarta, Bina Aksara, 1983,Hal.30

${ }^{15}$ Ibid, Hal.138.

${ }^{16}$ Moeljatno, Asas-Asas Hukum Pidana, Jakarta, Rineka Cipta, 2019. Hal.174.

${ }^{17}$ Leden Marpaung, Asas Teori Praktik Hukum Pidana, Jakarta Sinar Grafika, 2017, Hal.25.

${ }^{18}$ Ibid, Hal.25.

${ }^{19}$ Moeljatno, Op.Cit, Hal.190.
} 
Dalam teori hukum pidana biasanya alasan-alasan yang menghapuskan pidana dibeda-bedakan menjadi:

1. Alasan pembenar, yaitu alasan yang menghapuskan sifat melawan hukumnya perbuatan, sehingga apa yang dilakukan oleh terdakwalalu menjadi perbuatan yang patut dan benar.

2. Alasan pemaaf, yaitu alasan yang menghapuskan kesalahan terdakwa. Perbuatan yang dilakukan oleh terdakwa tetap bersifat melawan hukumjadi tetap merupakan perbuatan pidana, tetapi dia tidak dipidana, karena tidak ada kesalahan. ${ }^{20}$

Alasan pemaaf terdapat perbedaan pengertian dan perbedaan implikasi dengan alasan pembenar. Perbedaan pengertian ini, oleh Hart dijelaskan bahwa pada alasan pembenar adalah suatu perbuatan yang dipertimbangkan yang menurut hukum mengakibatkan tindak pidana. Pada alasan pemaaf merupakan tidak dapat dipertanggungjawabkan yang mendasarkan pada perkecualian. Pada saat melakukan suatu perbuatan sebagai disesalkan, tetapi karena keadaan psychologis pembuat ketika melakukan suatu perbuatan itu terdapat satu atau beberapa kondisi, kondisi pembuat itu tidak terlepas dari hukum dan tidak dipidananya pembuat. Hal ini merupakan kebutuhan keadilan atau keadilan kepada individu. ${ }^{21}$

Pada masa awalnya, cybercrime didefinisikan sebagai kejahatan computer. Mengenai defisini kejahatan komputer sendiri, samapai sekarang para sarjana belum sependapat mengenai pengertian atau definisi dari kejahatan komputer. Bahkan penggunaan istilah tindak pidana untuk kejahatan komputer dalam bahasa inggris pun masih masing belum seragam. ${ }^{22}$ Sebelum mengurai pengertian cyber crime secara terperintis maka terlebih dahulu akan dijelaskan "induk" cybercrimes yaitu cyber space. Cyber space dipandang sebagai sebuah dunia komunikasi yang berbasis komputer. Dalam hal ini, cyber space dianggap sebagai sebuah realitas baru dalam kehidupan manusia yang dalam bahasa sehari-hari dikenal dengan internet. ${ }^{23}$

The British Law Commission, mengartikan "computer fraund" sebagai manipulasi komputer dengan cara apa pun yang dilakukan dengan itikad buruk untuk memperoleh uang barang atau keuntungan lainnya atau dimaksudkan untuk menimbulkan kerugian pihak lain. Mandell membagi "computercrime" atas dua kegiatan, yaitu:

1. Penggunaan kompoter untuk melaksanakan perbuatan penipuan, pencurian atau penyembunyian yang dimaksud untuk memporoleh keuntungan keuangan, keuntungan bisnis, kekayaan atau pelayanan.

2. Ancaman terhadap komputer itu sendiri, seperti pencurian perangkat keras atau lunak sabotase dan pemerasan. ${ }^{24}$

Dari berbagai pengertian computer crime di atas, maka dapat dirumuskan bahwa computer crime merupakan perbuatan melawan yang dilakukan dengan memakai komputer sebagai sarana/alat atau komputer sebagai objek, baik untuk memperoleh keuntungan ataupun tidak, dengan merugikan pihak lain. ${ }^{25}$ Oleh karena itu, pada dasarnya cybercrime meliputi semua tindak pidana yang berkenaan dengan sistem informasi, system informasi (information system) itu sendiri, serta sistem komunikasi yang merupakan sarana untuk

\footnotetext{
${ }^{20}$ Ibid, Hal.148.

${ }^{21}$ Agus Rusianto, Op.Cit, Hak.161.

${ }^{22}$ Budi Suhariyanto, Tindak Pidana Teknologi Informasi (Cybercrime), Jakarta, Rajawali Pers, 2013,

${ }^{23}$ Maskun, Kejahatan Siber Cyber Crime, Jakarta, Kencana, 2019, Hal.46.

${ }^{24}$ Budi Suharianto, Op.Cit, Hal.9-.10.

${ }^{25}$ Maskun, Op.Cit. Hal.47-48.
} Hal. 9. 
penyampaian/pertukaran informasi kepada pihak lainnya (transmitter/originator to reciptient). ${ }^{26}$

Tindak pidana sengaja dan tanpa hak mengirimkan informasi elektronik yang berisi ancaman kekerasan atau menakut-nakuti adalah perbuatan melawan hukum yang menakutnakuti dengan memberi ancaman kekerasan yang dilakukan dengan memakai komputer sebagai sarana/alat atau komputer. Dalam pasal ini menjelaskan bahwa setiap orang yang mengancam dan menakut-nakuti orang lain melalui komputer, jika terbukti melakukan perbuatan tersebut maka orang itu dapat dipidana.

\section{Metode}

Adapun penelitian ini metode analisis yang dilakukan untuk mengumpulkan data dengan cara studi kepustakaan. Dalam penelitian ini, bahan hukum primer peraturan perundang-undangan yaitu Undang-Undang Nomor 35 Tahun 2009. Adapun penelitian bahan hukum sekunder berupa publikasi tentang hukum, berbagai literature yang berkaitan dengan masalah yang diteliti serta mengutip beberapa pendapat sarjana kemudian menyusunnya dengan sistematis untuk menjawab permasalahan pada Putusan Nomor 70/Pid sus/2019/Pn Bjn. Bahan hukum yang dilakukan dalam penulisan penelitian ini adalah dengan cara kualitatif yaitu, analisis terhadap isi putusan Pengadilan Negeri Bojonegoro Nomor:70/Pid sus/2019/Pn Bjn. Tentang dasar pertimbangan hakim menjatuhkan pidana mati kepada pelaku yang menawarkan perkerjaan prostitusi online, kemudian dilakukan pembahasan dan penafsiran yang ada pada akhirnya dapat ditarik kesimpulan tentang masalah-masalah yang diteliti.

\section{Pembahasan Dan Hasil}

Pertanggungjawaban pidana adalah dipidananya seseorang tidaklah cukup apabila orang itu telah melakukan perbuatan yang bertentangan dengan hukum atau bersifat melawan hukum. Jadi, meskipun perbuatan tersebut memenuhi rumusan delik dalam undang-undang dan tidak dibenarkan, namun hal tersebut belum memenuhi syarat penjatuhan pidana, yaitu orang yang melakukan perbuatan itu mempunyai kesalahan atau bersalah. Orang tersebut harus dipertanggungjawabkan atas perbuatannya atau jika dilihat dari sudut perbuatannya, perbuatannya baru dapat dipertanggungjawabkan kepada orang tersebut.

Tidaklah ada gunanya untuk mempertanggungjawabkan terdakwa atas perbuatannya apabila perbuatannya itu sendiri tidak bersifat melawan hukum, maka lebih lanjut dapat pula dikatakan bahwa terlebih dahulu harus ada kepastian tentang adanya perbuatan pidana, dan kemudian semua unsur-unsur kesalahan harus dihubungkan pula dengan perbuatan pidana yang dilakukan, sehingga untuk adanya pertanggungjawaban pidana yang mengakibatkan dipidanannya terdakwa maka terdakwa haruslah ada unsurunsur pertanggungjawaban pidana sebagai berikut:

a. Melakukan perbuatan pidana;

Perbuatan pidana adalah Perbuatan yang dilarang oleh suatu aturan hukum larangan mana disertai ancaman (sanksi) yang berupa pidana tertentu, bagi barang siapa melangggar larangan tersebut. Bahwa terdakwa Yuliatin Binti Maskun pada hari senin tanggal 07 januari 2019 sekira jam 21.00 wib, atau setidak-tidaknya pada suatu waktu dalam bulan Januari 2019 atau setidaktidaknya dalam tahun 2019 bertempat di Hotel Olympic turut jalan veteran Bojonegoro atau pada suatu tempat lain yang masih termasuk dalam daerah

\footnotetext{
${ }^{26}$ Budi Suharianto, Op.Cit, Hal.11.
} 
hukum Pengadilan Negeri Bojonegoro, yang berwenang untuk memeriksa dan mengadili, "Setiap Orang dengan sengaja dan tanpa hak mendistribusikan dan/atau mentransmisikan dan/atau membuat dapat diaksesnya Informasi Elektronik dan/atau Dokumen Elektronik yang memiliki muatan yang melanggar kesusilaan” dan juga terdakwa terdakwa Yuliatin Binti Maskun telah terbukti bersalah melakukan Tindak Pidana sebagai Mucikari sebagaimana diatur dan diancam pidana dalam Pasal 296 KUHP

Maka penulis menarik kesimpulan bahwa perbuatan terdakwa merupakan perbuatan pidana, dimana terdakwa menawarkan pekerjaan prostitusi online dimana perbuatan terdakwa tersebut termasuk perbuatan pidana karena telah diatur dalam suatu aturan hukum dalam UU RI Nomor 11 Tahun 2008 Tentang Informasi dan Transaksi Elektronik.

b. Mampu bertanggung jawab;

Dalam hal ini pelaku menyadari perbuatannya tersebut dapat merugikan orang lain adanya perbuatan yang dilakukan pelaku dengan adanya niat yang bersifat tujuan sehingga perbuatannya tersebut dapat dipertanggungjawaban. terdakwa juga menerima putusan hakim yang dimana pidananya 1 (satu) tahun 2 (dua) bulan. Bahwa terdakwa mampu bertanggungawab bahwa terdakwa tidak memiliki gangguan jiwa dan tidak cacat dalam pertumbuhan (idiot) hal ini dapat dilihat dalam pertimbangan hakim bahwa terdakwa menghendaki dan mengetahui secara sadar akibat yang ditimbulkan dari perbuatannya yang bertujuan untuk mendapatkan keuntungan. Dengan kesengajaan atau kealpaan

Terdakwa Yulianti Binti Maskun tahu dan mengendaki dilakukannya perbuatannya mendistribusikan dan/atau mentransmisikan dan/atau membuat diaksesnya informasi elektronik dan/atau dokumen elektronik yang memiliki muatan yang melanggar kesusilaan.

Agar terpenuhinya suatu perbuatan sebagai suatu tindak pidana harus memenuhi unsur sifat melawan hukum dan kesalahan. Kesalahan dalam arti luas, meliputi sengaja. Unsur dalam kasus Putusan No.27/Pid.Sus/2019/PN Bjn bahwa terdakwa menawarkan perkerjaan prostitusi online melalui aplikasi WhatsApp kepada wanita-wanita penjajah seks komersial. Majelis hakim menimbang bahwa berdasarkan fakta-fakta tersebut terdakwa mempunyai tujuan untuk mendapatkan keuntungan. Hal inilah yang membuat terdakwa memenuhi unsur kesengajaan.

c. Tidak adanya alasan pemaaf.

Salah satu unsur alasan pemaaf adalah daya paksa dimana sesorang diberikan alasan pemaaaf bila dalam melakukan perbuatannya terdapat daya paksa sedangkan dalam Putusan No.27/Pid.Sus/2019/PN Bjn terdakwa tidak memiliki upaya paksaan hal ini dapat dilihat dari keterangan terdakwa bahwa terdakwa dalam menawarkan pekerjaan prostitusi online kepada para pekerja seks komersial merupakan niat dari dalam diri terdakwa sendiri tanpa adanya upaya paksaan dari pihak manapun.

Berdasarkan unsur-unsur alasan pemaaf diatas, Majelis Hakim tidak menemukan hal-hal yang dapat menghapuskan pertanggungjawaban pidan sebagai alasan pembenar maupun alasan pemaaf, maka terdakwa harus mempertanggungjawabkan perbuatan dank arena terdakwa mampu bertanggungjawab maka terdakwa harus dinyatakan bersalah dan dijatuhi pidana.

Hal inilah yang membuat penulis sependapat dengan putusan hakim dalam menjatuhkan putusan pidana pokok terhadap terdakwa berupa pidana penjara selama 1 (satu) tahun dan 2 (dua) bulan, hal ini membuktikan bahwa hakim tidak memutus dibawah 
atau sama dengan tuntutan yang diberikan penuntut umum namun hakim bisa memberikan hukuman lebih dari tuntutan penuntut umum karena hakim memiliki pertimbangan sendiri dan tidak bertentangan dengan undang-undang. Hal ini dapat memberikan efek jera kepada terdakwa agak terdakwa tidak mengulangi perbuatannya lagi.

\section{Kesimpulan dan Saran}

Dalam perkara putusan Nomor 70/Pid.Sus/2019/Pn Bjn, Jaksa mendakwa terdakwa dengan dakwaan kesatu yakni Pasal 27 Ayat (1) jo Pasal 45 Ayat (1) UU RI No 19 tahun 2016 tentang perubahan atas UU No 11 tahun 2008 tentang ITE dan unsur-unsur dalam pasal tersebut telah terpebuhi dan dakwaan kedua Pasal 296 KUHP dan unsur-unsur dalam dakwaan tersebut telah terpenuhi. Maka Jaksa hanya menuntut terdakwa dengan dakwaan kedua yaitu selama 1 (satu) tahun. Majelis Hakim tidak menemukan hal-hal yang dapat menghapuskan pertanggungjawaban pidana sebagai alasan pembenar dan alasan pemaaf, maka terdakwa harus mempertanggungjawabkan perbuatan dan karena terdakwa mampu bertanggungjawab maka harus dinyatakan bersalah dan dijatuhi pidana penjara selama satu 1 (satu) tahun 2 (dua) bulan. Perlu penindakan secara tegas terhadap pelaku prustitusi online, maka diharapkan kepada Aparat Penegak Hukum terutama Hakim memberikan sanksi yang berat agar pelaku tindak pidana prostitusi online mendapatkan efek jera .

\section{DAFTAR PUSTAKA}

\section{Buku}

Ali, Mahrus. 2015. Asas-Asas Hukum Pidana Korporasi. Jakarta: Raja Grafindo Persada Ali, Mahrus. 2015. Dasar-Dasar Hukum Pidana. Jakarta: Sinar Grafika Siburian, Kasman. 2017, Hukum Administrasi Negara. Yogyakarta: Capiah Manullang, Herlina. 2010. Pengantar Ilmu Hukum Indonesia. Medan: UHN Press Amrani, Hanafi, 2015. Sistem Pertanggungjawaban Pidana. Jakarta: Rajawali Press

Saleh, Roeslan. 1985. Perbuatan Pidana Dan Pertanggungjawaban Pidana. Jakarta: Aksara Baru

Saleh, Roeslan. 1982. Pikiran-pikiran Tentang Pertanggungjawaban Pidana. Jakarta: Ghalia Indonesia

Rusianto, Agus. 2018. Tindak Pidana Dan Pertanggungjawaban Pidana. Jakarta: Prenadamedia Grup

Salah, Roeslan, 1985. Perbuatan Dan Kesalahan Dalam Hukum Pidana, Jakarta: Aksara Baru

Poernomo, Bambang. 2018. Asas-Asas Hukum Pidana. Jakarta: Ghalia Indonesia

Moeljatno. 1983. Perbuatan Pidana dan Pertanggungjawaban dalam Hukum Pidana. Jakarta: Bina Aksara

Moeljatno. 2019. Asas-Asas Hukum Pidana. Jakarta: Rineka Cipta

Marpaung, Leden. 2017. Asas Teori Praktik Hukum Pidana. Jakarta: Sinar Grafika

Suhariyanto, Budi. 2013. Tindak Pidana Teknologi Informasi (Cybercrime). Jakarta: Rajawali Pers

Maskun. 2019. Kejahatan Siber Cyber Crime. Jakarta: Kencana

Adami Chazwi dan Ardi Ferdinan. 2015. Tindak Pidana Informasi \& Transaksi Elektronik. Malang: Media Nusa Creative

Kartono, Kartini. 2015. Patologi Sosial. Jakarta: Rajawaki Pers 


\section{Jurnal}

Alvionita Rhiza dan Pramesthi Dya. Kajian Yuridis Terhadap Prostitusi Online. Jurnal UNS. 2013.

Anggusti, M., \& Anggusti, Y. (2020). PENEGAKAN HUKUM DI INDONESIA DALAM RANGKA TATA KELOLA PEMERINTAHAN YANG LEBIH BAIK MENUJU 100 TAHUN KEMERDEKAAN INDONESIA (2045). Nommensen Journal of Legal Opinion, 1(01), 38-52. https://doi.org/10.51622/njlo.v1i01.37

Habeahan, B., \& Tamba, A. R. . (2021). PERLINDUNGAN HUKUM PEMBELI DALAM PERJANJIAN JUAL BELI MELALUI SISTEM ELEKTRONIK. Nommensen Journal of Legal Opinion, 2(01), 47-54. https://doi.org/10.51622/njlo.v2i01.208

\section{Peraturan Perundang-Undang}

Undang-Undang Nomor 19 Tahun 2016 tentang perubahan atas Undang-Undang Nomor 11 Tahun 2008 tentang Informasi dan Transaksi Elektronik 